\title{
A Timetable of Events During Programmed Cell Death Induced by Trophic Factor Withdrawal from Neuronal PC12 Cells
}

\author{
Peter W. Mesner, Conrad L. Epting, Joseph L. Hegarty, and Steven H. Green \\ Department of Biological Sciences, University of lowa, lowa City, lowa 52242-1324
}

\begin{abstract}
We describe a timetable of events during programmed cell death (PCD) in neuronal PC12 cells, specifically, Ras signaling, immediate-early gene (IEG) expression, DNA fragmentation and commitment to PCD. Commitment occurs over a period from 10-20 $\mathrm{hr}$ after NGF withdrawal. Ras signaling declines rapidly after NGF removal, reaching minimal levels within 2-4 hr, well before the onset of commitment. DNA fragmentation, detected by TUNEL reaction, begins about $24 \mathrm{hr}$ after NGF withdrawal, well after all cells are committed, but coincident with the onset of cell dissolution previously determined by trypan blue exclusion (Mesner et al., 1992). Among the IEGs studied here, c-jun and TIS21 are expressed within $6 \mathrm{hr}$ after NGF withdrawal. Expression of c-fos, egr-1, and TIS11 does not begin until $20 \mathrm{hr}$ after NGF withdrawal. IEG expression generally ends by $24 \mathrm{hr}$ after NGF withdrawal. The IEGs TIS7 and nur77 are not expressed during $P C D$, yielding a pattern distinct from that following other stimuli. An identical pattern of IEG expression occurs in non-neuronal PC12 cells deprived of serum, although expression begins at 10-14 hr after serum withdrawal. A similar IEG expression pattern was observed in Rat-1 fibroblasts, with various genes expressed 6-18 hr after serum withdrawal. In none of these cell types did expression of the stress-related gene Hsp70 change following trophic factor withdrawal. The distinctive pattern of IEG expression described here should facilitate identification of intracellular regulatory signals active during PCD.
\end{abstract}

[Key words: apoptosis, programmed cell death, trophic factor, NGF, neurotrophic factor, immediate-early gene expression, PC12 cell, Ras]

Programmed cell death (PCD), or apoptosis, is a physiological process, typically marked by nuclear condensation and DNA fragmentation, used to eliminate supernumerary or deleterious cells. In the nervous system, survival depends upon availability of neurotrophic factors: neurons lacking sufficient trophic support undergo PCD (Oppenheim, 1991). NGF promotes the survival of various central and peripheral neurons in vivo and in vitro (Barde, 1989) and promotes survival and neuronal differ-

\footnotetext{
Received May 9, 1995; revised June 29, 1995; accepted July 6, 1995.

Support for this study was from a Carver Scientific Research Initiative Grant and a University of lowa Diabetes and Endocrinology Research Core Seed Grant, funded by NIH Grant DK25295. We thank Drs. Dalla-Favera, Herschman, Kaneda. Milbrandt, and Wu for providing cDNAs.

Correspondence should be addressed to Steven H. Green, Department of Biological Sciences, University of Iowa, 138 Biology Building, Iowa City, IA $52242-1324$.

Copyright 1995 Society for Neuroscience $0270-6474 / 95 / 157357-10 \$ 05.00 / 0$
}

entiation of PC12 cells (Greene and Tischler, 1976; Greene, 1978).

Responses to NGF are mediated by the TrkA receptor tyrosine kinase (Kaplan et al., 1991a,b; Klein et al., 1991; Loeb et al., 1991), which activates several intracellular signaling molecules including Ras (Qiu and Green, 1991) and phosphatidylinositol-3 kinase (PI-3-K) (Carter and Downs, 1992; Ohmichi et al., 1992: Soltoff et al., 1992). Ras activation appears necessary for NGF promotion of PC12 neuronal differentiation (Hagag et al., 1986; Szeberényi et al., 1990). Expression of mutant activated Ras promotes neuronal differentiation (Bar-Sagi and Feramisco, 1985; Noda et al., 1985) and survival (Borasio et al., 1989; Rukenstein et al., 1991). PI-3-K activity is associated with promotion of survival by NGF (Yao and Cooper, 1995).

Unlike sympathetic neurons, $\mathrm{PC} 12$ cells can survive in serumcontaining medium whether or not NGF is present. If maintained in serum-free medium in the presence of NGF, PC12 cells will undergo neuronal differentiation, and will die when NGF is withdrawn (Greene, 1978; Greene et al., 1986). The death of NGF-deprived neuronally differentiated PCl2 cells resembles PCD in neurons-and in many non-neuronal cells--in that the death is blocked by inhibitors of RNA or protein synthesis (Tata, 1966; Lockshin, 1969; Pratt and Greene, 1976; Martin et al., 1988; Scott and Davies, 1990; Mesner et al., 1992). Non-neuronal PC12 cells die when serum is removed and, in contrast to the neuronally differentiated cells, their death is not blocked by RNA and protein synthesis inhibitors (Mesner et al., 1992). This and other similarities between neuronal PC12 cells and sympathetic neurons establish PC12 cells as a model for neuronal PCD.

The ability of protein synthesis inhibitors to prevent PCD suggests that gene expression is required for PCD. Indeed, activation of specific genes has been associated with PCD in several systems (Osbourne and Schwartz, 1994), for example, c-fos, c$m y c$, and TRPM-2 are expressed in prostate epithelium during castration-induced regression (Buttyan et al., 1988) and cyclin D1 is expressed in NGF-deprived sympathetic neurons (Freeman et al., 1994). Immediate-early gene (IEG) expression is associated with PCD: examples include nur 77 expression during T-cell hybridoma death induced by ligation of antigen receptors (Liu et al., 1993; Woronicz et al., 1993) and c-fos expression during PCD in many neuronal and non-neuronal tissues (Smeyne et al., 1993). In sympathetic neurons, expression of IEGs of the Fos and Jun families, as well as c-myb and $e g r-1$, has been detected following NGF deprivation in vitro (Estus et al., 1994), expression of c-jun was detected following lesion in vivo (Koistinaho et al., 1993). Moreover, expression of c-jun appears necessary for sympathetic neuronal PCD (Estus et al., 1994; Ham et al., 1995). 
As an initial step in determining causal relationships among PCD-associated events such as DNA fragmentation and gene expression, it is necessary to define their temporal relationships to each other, to termination of trophic factor-dependent intracellular signaling, and to commitment to cell death. We investigated these issues using, primarily, neuronally differentiated PC 12 cells. We describe a distinctive pattern of IEG expression following trophic factor withdrawal and place it within the temporal context of critical post-withdrawal events: commitment to cell death, cessation of Trk-induced intracellular signaling, and onset of cell dissolution.

\section{Materials and Methods}

Cell culture and trophic factor deprivation. $\mathrm{PCl} 2$ cells (passages 2934) were maintained as described in (Greene and Tischler, 1976) on collagen-coated tissue culture dishes in RPMI 1640 medium containing $10 \%$ fetal bovine serum (GIBCO), 5\% donor horse serum (JRH Biosciences). $100 \mathrm{U} / \mathrm{ml}$ penicillin and $100 \mu \mathrm{g} / \mathrm{ml}$ streptomycin; mediun changed three times weekly. Sera were heat-inactivated at $56^{\circ} \mathrm{C}$ for 30 min. NGF was prepared from male mouse submaxillary glands, essentally as described by Mobley et al. (Mobley et al., 1972). Neuronal $\mathrm{PC} 12$ cell cultures were prepared by treating $\mathrm{PC} 12$ cells with $50 \mathrm{ng} / \mathrm{ml}$ NGF for at least 2 weeks (Greene et al., 1986). In these experiments. NGF treatment was initiated by replating PC12 cells, at $2.5 \times 10^{6}$ cells/ $100 \mathrm{~mm}$ dish, in RPMI 1640 medium containing I\% heat-inactivated donor horse serum and NGF. This small amount of serum provides nn long-term trophic support but is used to facilitate changing the medium. The serum eliminates surface tension that can sometimes cause cells to peel off the plate when serum free medium is repeatedly exchanged.

The total time allowed for neuronal differentiation in NGF was generally $15 \mathrm{~d}$. The cells were maintained for $12 \mathrm{~d}$ in RPMI containing $1 \%$ horse serum and NGF, (changed three times per week). The culture medium was then changed to $50 \mathrm{ng} / \mathrm{ml} \mathrm{NGF}$ in serum-free RPMI. The cells were cultured in this medium without serum for an additional three days to facilitate subsequent complete withdrawal of trophic factor. NGF deprivation was accomplished by washing the cells twice with sterile phosphate-buffered saline (PBS) and then maintaining the cells in RPMI until the cells were counted.

Non-neuronal PC12 cells at moderate density $\left(1-2 \times 10^{7}\right.$ cells $/ 100$ $\mathrm{mm}$ dish) were deprived of serum by washing twice with sterile PBS and then maintaining the cells in serum-free RPMI until the cells were counted. The cells were at equal density in each experiment.

Rat 1 fibroblasts (passages 18 24) were maintained in DMEM containing $10 \%$ heat-inactivated fetal bovine serum, $100 \mathrm{U} / \mathrm{mL}$ penicillin and $100 \mu \mathrm{g} / \mathrm{ml}$ streptomycin, on untreated plastic tissue culture dishes. For trophic factor deprivation, subconfuent cells in 100 nim dishes were washed twice with sterile PBS and then maintained in serum-free DMEM until the cells were counted. The cells were at equal density in each experiment.

Cell death assay. To count viable cells, cells were removed from dishes by trituration in their culture medium (to avoid loss of detached cells). Cells were concentrated by brief centrifugation ( $1000 \times g, 5$ min), the supernatant was removed, and the cells resuspended in 100 $\mu \mathrm{l}$ of PBS and $100 \mu \mathrm{l}$ of trypan blue solution $(0.4 \%$ trypan blue, $0.81 \%$ $\mathrm{NaCl}$ and $0.06 \% \mathrm{~K}_{2} \mathrm{HPO}_{4}$ ). Live (trypan blue-excluding) cells were counted using a hemacytometer.

Determination of Ras activity. PC12 cells were plated in $35 \mathrm{~mm}$ wells $\left(1.5 \times 10^{6}\right.$ cells/well $) 2-3 \mathrm{~d}$ before an experiment. The cells were not exposed to fresh serum after plating as this alone is sufficient to increase Ras.GTP levels. The wells were washed wilt HBSG (HEPES-buffered saline + glucose: $137 \mathrm{~mm} \mathrm{NaCl}, 2.7 \mathrm{mM} \mathrm{KCl}, 1.2 \mathrm{mM} \mathrm{CaCl}_{2}, 0.5 \mathrm{~mm}$ $\mathrm{MgCl}_{2}, 1 \mathrm{mg} / \mathrm{ml}$ glucose, $25 \mathrm{~mm}$ HEPES, $\mathrm{pH} 7.4$ ) and ${ }^{32} \mathrm{P}_{-} \mathrm{PO}_{4}$ (ICN) was added in $\mathrm{HBSG}(200-300 \mathrm{mCi} / \mathrm{ml})$. The cells were incubated in ${ }^{32} \mathrm{P}_{-} \mathrm{PO}_{4}$ for $2 \mathrm{hr}$ at $37^{\circ} \mathrm{C}$. The incubations were stopped by rapid removal of medium and washing with ice-cold phosphate-buffered saline (PBS). The cells were lysed in $0.5 \mathrm{ml}$ of ice-cold lysis buffer A (1\% Triton $\mathrm{X}-100,100 \mathrm{mM} \mathrm{NaCl}, 5 \mathrm{~mm} \mathrm{MgCl}, 10 \mathrm{~mm}$ benzamidine (Calbiochem), $1 \mathrm{mg} / \mathrm{ml}$ BSA. $10 \mathrm{mg} / \mathrm{ml}$ leupeptin, $10 \mathrm{mg} / \mathrm{ml}$ aprotinin, $50 \mathrm{~mm}$ HEPES, $\mathrm{pH} 7.4$ ). The lysate was incubated for $3 \mathrm{hr}$ on a rotator with protein Asepharose (Pharmacia) $(35 \mu \mathrm{l} / \mathrm{sample})$ precoated with rabbit anti-rat IgG. The sepharose was removed by a $5 \mathrm{~min}$ centrifugation in a microcentrifuge. Ras was immunoprecipitated with culture supernatant (45 $\mu \mathrm{l} / \mathrm{sample}$ ) from hybridoma Y 13-259 (Furth et al., 1982). The Y13-259 supcrnatant or control culture supernatant was added to the lysate and incubated on ice for $60 \mathrm{~min}$. Rabbit anti-rat protein A-sepharose (25 $\mu 1 /$ tube) was then added and the mixture incubated overnight on a rotator at $4^{\circ} \mathrm{C}$. The immunoprecipitate was washed eight times with $1 \mathrm{ml}$ of wash buffer $\left(500 \mathrm{~mm} \mathrm{NaCl}, 5 \mathrm{~mm} \mathrm{MgCl}_{2}, 0.1 \%\right.$ Triton X-100. $0.005 \%$ SDS, $50 \mathrm{~mm}$ HEPES, pH 7.4). Guanine nucleotides were eluted from the immunoprecipitate with elution buffer ( $2 \mathrm{~mm}$ EDTA. $2 \mathrm{~mm}$ dithiothreitol, $0.2 \%$ SDS, $0.5 \%$ GTP, $0.5 \%$ GDP). The eluted guanine nucleotides were separated on PEI-cellulose thin-layer chromatography (TLC) plates run in $0.75 \mathrm{M} \mathrm{KH}_{2} \mathrm{PO}_{+}, \mathrm{pH} 3.4$ (Satoh, 1988 \#266) and the positions of GTP and GDP were identified with a short-wave UV lamp. The plates were then dried and exposed to preflashed Kodak XAR-5 film with a Du Pont Lightning Plus intensifying screen at $-86^{\circ} \mathrm{C}$. Autoradiograms were scanned on a Hoefer densitometer for quantitation of radioactivity. The molar ratio of GTP to GDP was corrected for the additional phosphate in GTP based on the assumption that all positions are equally labeled with ${ }^{32} \mathrm{P}$.

RNA extraction and Northern blotting. Polyadenylated RNA was prepared from cultured cells using oligo(dT) cellulose spin columns (Badley et al., 1988). Samples of mRNA $(2 \mu \mathrm{g})$ were applied to $1.1 \%$ denaturing agarose gels for electrophoresis and vacuum transferred to ZetaProbe GT Nylon membranes (Bio-Rad). Blots were hybridized with $\mathrm{NaOH}$-denatured, "2P-labeled cDNA probes and exposed to Kodak X-Omat AR x-ray film (Kodak) with two Du Pont Lightning Plus intensifying screens (Dupont) for $12-48 \mathrm{hr}$ at $-86^{\circ} \mathrm{C}$. Probes were prepared by random hexamer priming of rat egr-I (NGFl-A) (Milbrandt, 1987), rat nur77 (NGFI-B) (Milbrandt, 1988), human c-myc (DallaFavera et al., 1982), murine hsp70 (S. Shtang), murine c-jim (Lamph et al., 1988), rat c-fos (Curran et al., 1987), rat GAPDH (Tso et al., 1985), murine TIS7 (Varnum et al., 1989), murine TIS2I (Fletcher et al., 1991), and rat TISII (Kaneda et al., 1992).

Westem blotting. Protein samples $(20 \mu \mathrm{g})$ were separated by SDSPAGE and transferred to Trans Blot nitrocellulose (Bio-Rad). After transfer, the filters were briefly stained with $0.05 \%$ w/v Ponceau red $S$ in $3 \% \mathrm{TCA}$, and the position of the molecular weight standards was marked. The filters were then blocked for at least $2 \mathrm{hr}$ in $1 \%$ bovine serum albumin (BSA) in TBST (Tris-buffered saline with $0.05 \%$ Tween 20. Primary antibody, anti-egr-1 (Santa Cruz Biotechnology) diluted $1: 100$ in $1 \%$ BSA in TBST was incubated with the filter. in a humidified container, for $2 \mathrm{hr}$ at $37^{\circ} \mathrm{C}$. The blot was then washed once briefly in TBST and $3 \times 15$ min in TBST containing $1 \%$ casein. The filter was then incubated with alkaline phosphatase conjugated anti-rabbit IgG (1: 2000 , Sigma), in a humidified container for $3 \mathrm{hr}$ at $37^{\circ} \mathrm{C}$. The filter was then washed as above, followed by a $15 \mathrm{~min}$ wash in TBST containing $0.1 \mathrm{~mm} \mathrm{MgCl}_{2}$ and $0.4 \mathrm{mM} \mathrm{ZnCl}_{2}$. Blots were developed in alkaline phosphatase buffer ( $100 \mathrm{~mm}$ Tris, $100 \mathrm{~mm} \mathrm{NaCl}, 5 \mathrm{mM} \mathrm{MgCl}_{2}$ ) containing $230 \mu \mathrm{g} / \mathrm{ml} \mathrm{BCIP}$ and $165 \mu \mathrm{g} / \mathrm{ml}$ nitro blue tetrazolium.

TUNEL (terminal dUTP-biotin nick end labeling) assay. A protocol modified from that of Gavrieli et al. (Gavrieli et al., 1992) was used. Neuronal PC12 cells were grown at low density in collagen-coated 96 well plastic tissue culture dishes. Following complete neuronal differentiation ( 2 weeks), NGF was withdrawn by rinsing the cells four times with RPMI 1640. The cells were then maintained for various times in serum-free RPMI 1640 containing anti-NGF antiserum (1:2000 dilution. Sigma).

Cells were fixed in $10 \%$ formalin, $5 \%$ sucrose overnight and then permeabilized with $0.1 \%$ Triton X-100 in PBS for 10 min. Cells were rinsed for $10 \mathrm{~min}$ in distilled water followed by two $10 \mathrm{~min}$ washes in terminal transferase buffer $\left(30 \mathrm{~mm}\right.$ Tris pH 7.2, $1 \mathrm{~mm} \mathrm{CoCl}_{2}, 140 \mathrm{~mm}$ sodium cacodylate). The terminal transferase labeling reaction was performed in terminal transferase buffer containing $20 \mu \mathrm{M}$ dUTP $+4 \mu \mathrm{m}$ biotinylated dUTP (Boehringer Mannheim) and $100 \mathrm{U} / \mathrm{ml}$ of terminal transferase (Boehringer Mannheim) at $37^{\circ} \mathrm{C}$ for $1 \mathrm{hr}$. The reaction was terminated by rinsing for $15 \mathrm{~min}$ in $300 \mathrm{~mm} \mathrm{NaCl} / 30 \mathrm{~mm}$ sodium citrate, then $10 \mathrm{~min}$ in PBS $+10 \mathrm{mg} / \mathrm{ml}$ BSA. Terminal transferase labeling was visualized by incubation with $1.25 \mu \mathrm{g} / \mathrm{ml}$ HRP-Z-avidin (Zymed) $+1 \mathrm{mg} / \mathrm{ml} \mathrm{BSA}$ in PBS for $30 \mathrm{~min}$ at $37^{\circ} \mathrm{C}$; then washing $2 \times 10 \mathrm{~min}$ with PBS $+1 \mathrm{mg} / \mathrm{ml}$ BSA, followed by a $10 \mathrm{~min}$ wash with $100 \mathrm{~mm}$ sodium acetate buffer ( $\mathrm{pH}$ 5.2). The cells were then incubated with 1.25 $\mathrm{mm} 3$-amino-9-ethylcarbazole (AEC) $+0.03 \% \mathrm{H}_{2} \mathrm{O}_{2}$ in $100 \mathrm{~mm}$ sodium acetate buffer for 5-10 min. at room temperature. Progress of the AEC reaction was monitored with a microscope and terminated by replacing the reaction solution with PBS. Labeled and unlabeled cells were counted with a Nikon Diaphot inverted microscope. 


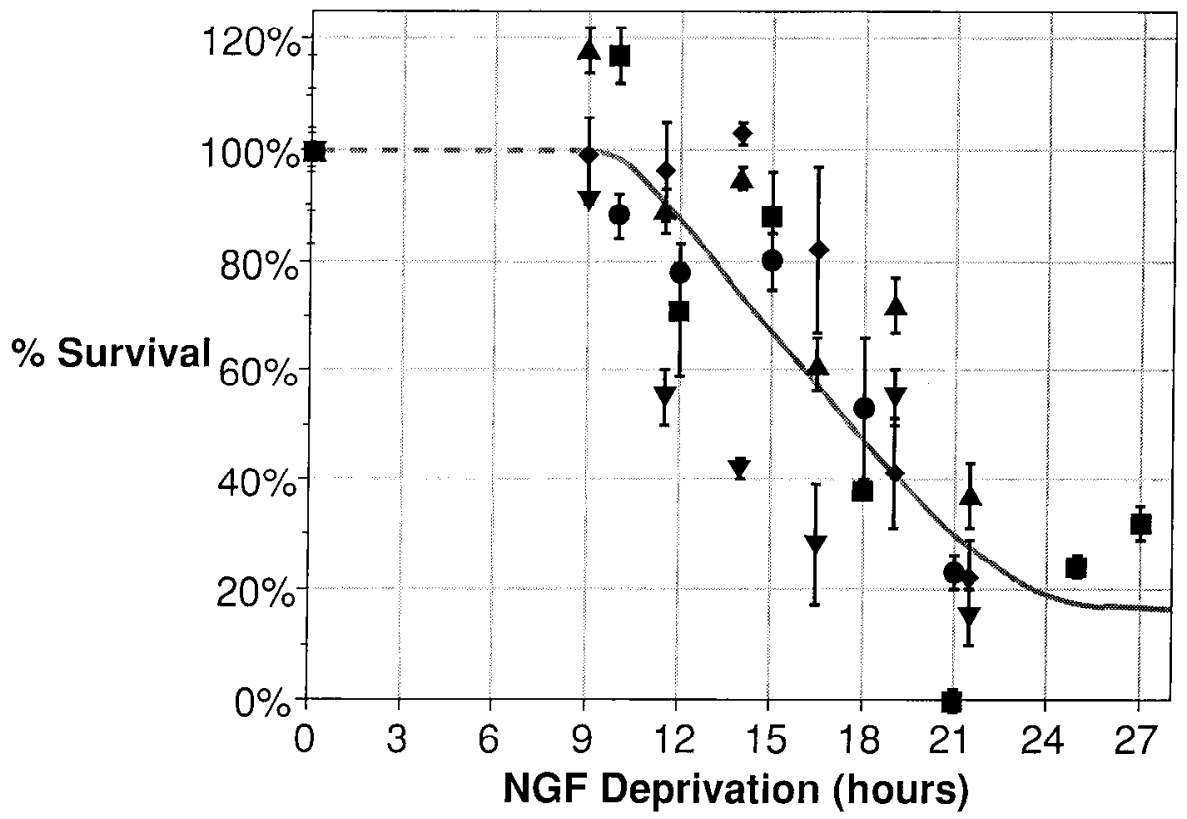

Figure 1. Commitment to PCD of neuronal PC12 cells deprived of trophic support for various lengths of time. Neuronal PC12 cell cultures were deprived of NGF as described in Materials and Methods. At various times after deprivation, NGF was readded to a concentration of $50 \mathrm{ng} / \mathrm{ml}$. The cells were then maintained until $84 \mathrm{hr}$ after the initial NGF withdrawal, at which time the number of viable cells was determined. Cell viability assays were performed by counting cells that exclude trypan blue. The data shown are from five separate experiments. Each experiment is represented by a different symbol. Error bars are SD of triplicate or quadruplicate samples. The solid line is a best fit third order polynomial. Since no commitment was observed at nine hours after withdrawal, commitment was not assayed prior to this time, as indicated by the broken line.

\section{Results \\ Neuronal PC12 cell commitment to PCD following trophic factor deprivation}

Commitment to cell death is defined as the time after which readdition of trophic support will no longer prevent cell death. Cell viability was assessed $84 \mathrm{hr}$ after NGF withdrawal, at which time $>80 \%$ of the cells have died. As shown in Figure 1, readdition of $\mathrm{NGF}$ up to $10 \mathrm{hr}$ after the initial withdrawal rescues all of the cells, that is, as many cells are viable after $84 \mathrm{hr}$ as in control cultures from which NGF was not withdrawn. Increasing the interval between NGF withdrawal and readdition results in a decreasing number of viable cells $84 \mathrm{hr}$ after withdrawal. Thus, neuronal PCI 2 cells become gradually committed to cell death over a period extending from 10 to $20 \mathrm{hr}$ after NGF withdrawal. About $50 \%$ of the cells are committed to cell death at about 16 hr after withdrawal.

\section{Ras activity declines rapidly in neuronal PC12 cells following} trophic factor deprivation

The GTP-binding protein Ras plays a critically important role in linking the NGF receptor tyrosine kinase, TrkA, to cellular responses. Ras activation has been shown to be necessary for PC1 2 cell responses to NGF. Constitutively active Ras is sufficient to maintain survival of PC'12 cells (Rukenstein et al., 1991) or sympathetic neurons (Borasio et al., 1989) even in the absence of NGF. Thus, Ras activity was chosen as the indicator of neurotrophic factor intracellular signaling.

Ras activity is determined as the ratio of Ras.GTP to Ras-GDP, as previously described (Qiu and Green, 1991), (Ras is active when bound to GTP, inactive when bound to GDP). Ras activity peaks within 5 min of initial NGF treatment of PC1 2 cells and then declines, but persists at a level significantly above prestimulus levels for at least 2 weeks of NGF treatment (M.-S. Qiu and S. H. Green, unpublished observations). Following NGF withdrawal from neuronally differentiated PC12 cells (described in Materials and Methods), Ras activity declines (Fig. 2 ). The decline continues for about $4 \mathrm{hr}$ by which time Ras activity reaches a new steady-state level of about $35 \%$ of the steady-state level that had been maintained during long-term
NGF treatment. This now level is comparable to the level of Ras activity in unstimulated non-neuronal $\mathrm{PC} 12$ cells prior to NGF treatment and is the minimal level of Ras activity observed in PC12 cells. These data show that Ras activity is rapidly downregulated in neuronal $\mathrm{PC} 12$ cells following NGF withdrawal.

A small increase in Ras activity is apparent shortly after NGF withdrawal (Fig. 2). This was observed in all three replicate experiments performed but its significance is not clear. While it may indicate signaling due to NGF withdrawal, this small effect may simply be an artefact of the change of medium.

\section{DNA fragmentation begins at 24 hr after NGF withdrawal from neuronal PC12 cells}

Our previous studies (Mesner et al.. 1992), which used trypan blue staining, suggested that the loss of viability begins at about $24 \mathrm{hr}$ after NGF withdrawal from neuronal PC12 cells. DNA fragmentation is a phenomenon that accompanies cell death in many diverse cell types (Wyllie et al., 1984; McConkey et al., 1989; Kure et al., 1991). Since it is likely to be an irreversible phenomenon, we wished to determine whether DNA fragmentation coincides with commitment or with loss of cell viability. If the former, DNA fragmentation could be causal to commitment to PCD, if the latter, DNA fragmentation is more likely to be part of the process of cell dissolution. Our previous electrophoretic analysis suggested that DNA cleavage was not detectable as a nucleosomal ladder in NGF-deprived neuronal PCI2 cells or SCG neurons (Mesner et al., 1992). However it was possible that DNA fragmentation resulting in larger fragments (e.g., $>20 \mathrm{kbp}$ ) was occurring and was not detected by our assay methods. We have therefore reexamined DNA cleavage with the TUNEL technique of Gavrieli et al. (Gavrieli et al., 1992), which specifically labels the DNA ends generated by endonuclease activity. This technique has an advantage over electrophoretic analysis in that DNA fragmentation can be detected even if the DNA is being cleaved into pieces too large to be resolved on conventional agarose gels.

In control NGF-treated neuronal PC12 cell cultures a background level of about $10 \%$ TUNEL-positive cells (detected as red-stained nuclei) was observed (Fig. 3). The fraction of TU- 
Figure 2. Ras activity in neuronal PC12 cells following NGF withdrawal. Ras was immunoprecipitated from lysates of ${ }^{32}$ P-labeled neuronal PC12 cell cultures at various times after NGF withdrawal. Bound guanine nucleotide was quantified as described in Methods. The basal GTP:GDP ratio associated with control cells from which NGF was not withdrawn is assigned a value of 1.0. The data shown are from a single experiment, typical of three performed.

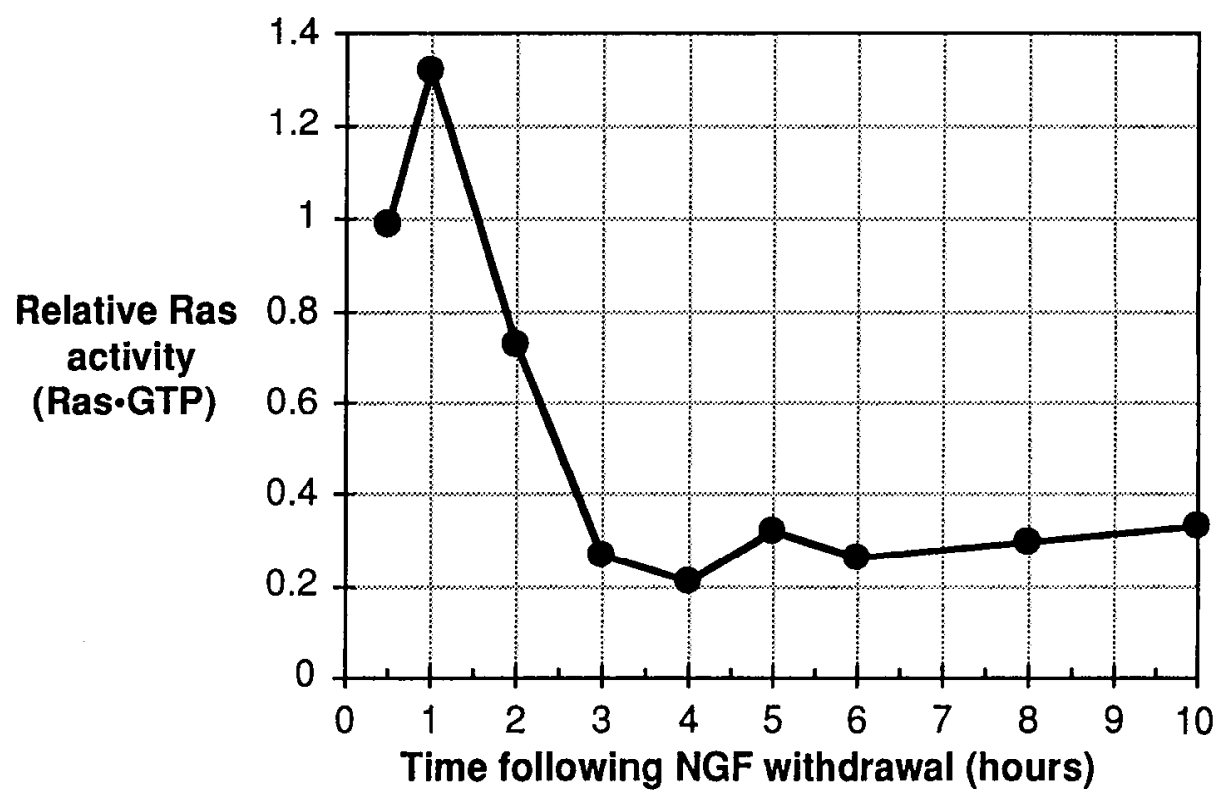

that DNA fragmentation occurs as a result of commitment to PCD rather than as a cause.

Differential immediate early gene expression in NGF-deprived neuronal PC12 cells

We have previously observed that PCD in neuronal PC12 cells is, at least in part, transcription-dependent (Mesner et al., 1992). Induction of IEGs typically accompanies alterations in a cell's pattern of gene expression. Expression of various IEGs has been previously noted to accompany the process of cell death (Buttyan et al., 1988; Buttyan et al., 1989; Liu et al., 1993; Woronicz et al., 1993) We therefore assayed the expression of various IEGs in neuronal PCl 2 cells to determine when transcriptional events occur following NGF withdrawal.

Northern blot analysis of neuronal PC 12 cell cultures deprived of NGF for various times revealed the induction of several IEGs (Fig. 4). Expression of the genes egr-1 (NGFI-A/Zif268), c-fos, $T I S 11$, and TIS21, barely detectable in control cells or in cells deprived of NGF for up to $18 \mathrm{hr}$, exhibits a dramatic four- to
Figure 3. DNA fragmentation in neuronal PC 12 cells following NGF withdrawal. Cells containing fragmented DNA were visualized by TUNEL labeling (Gavrieli et al., 1992). The proportion of TUNEL-positive cells was determined by counting cells with a microscope. Error bars represent SD of quadruplicate data.
$\%$ TUNEL positive cells

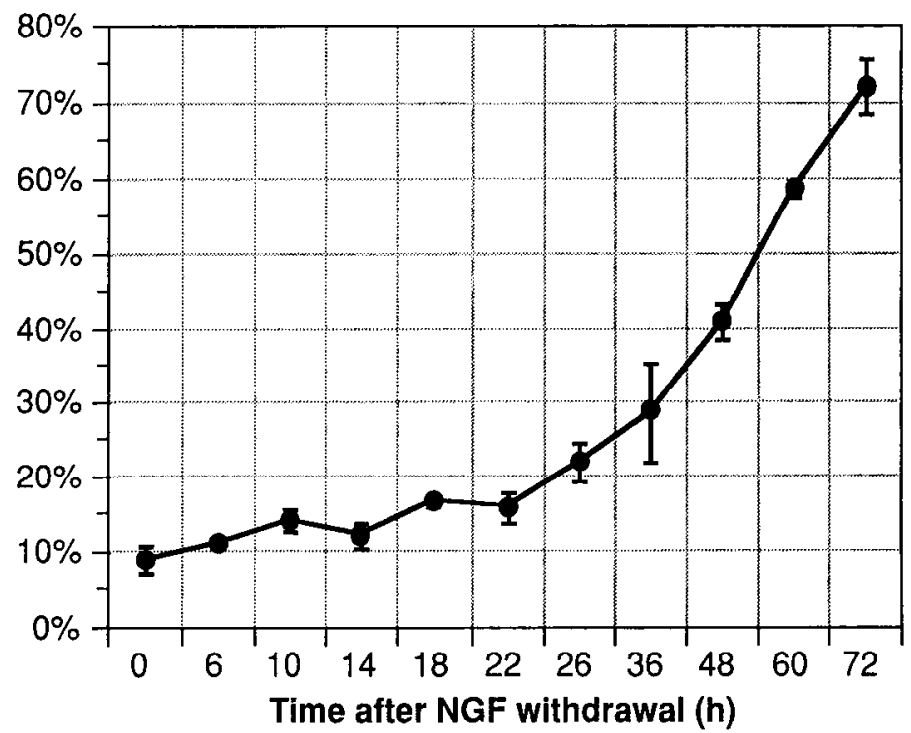




\section{Neuronal PC12 Cells - NGF Withdrawal $06 h \cdot 10 h \cdot 14 h \cdot 18$ h 22 h 26 h 48 h $\left.\right|_{\text {add'n }} ^{\text {NGF }}$}
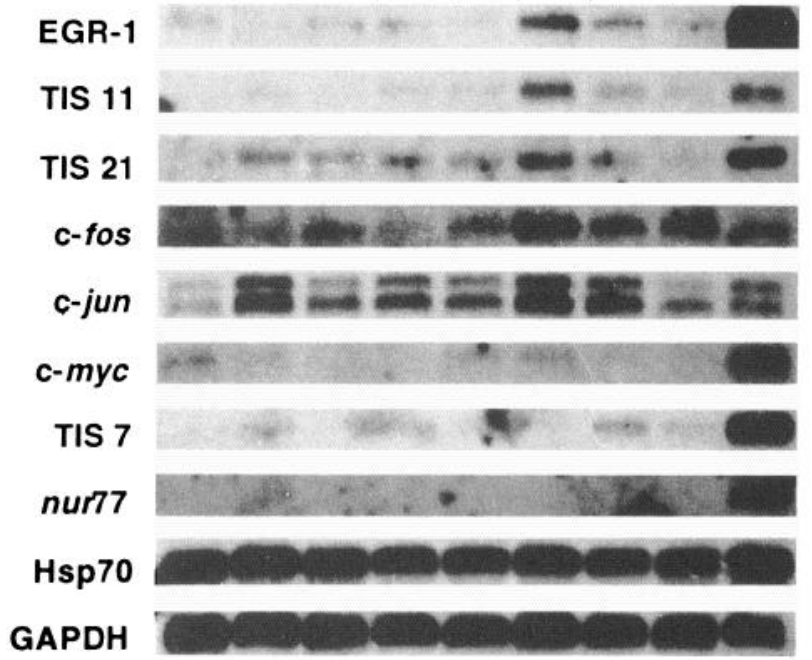

Figure 4. IEG expression in neuronal PC12 cells following NGF withdrawal. Polyadenylated mRNA $(2 \mu \mathrm{g} / \mathrm{lane})$ was prepared from neuronal $\mathrm{PC} 12$ cell cultures deprived of NGF in serum-free medium for various times. Blots were probed for expression of IEGs indicated. The Hsp70 probe was employed to assess expression of stress-related genes and GAPDH to assess mRNA integrity and to compare loading among the lanes. mRNA from PC12 cells treated with NGF at $50 \mathrm{ng} / \mathrm{ml}$ for $1.5 \mathrm{hr}$ was employed as a positive control for IEG expression.

fivefold induction approximately $22 \mathrm{hr}$ after NGF-withdrawal. The observed inductions appear to be transient; transcript levels were significantly lower by $26 \mathrm{hr}$ after NGF withdrawal. After $48 \mathrm{hr}$ of NGF deprivation expression levels of egr-1, TIS I1, and TIS 21 had returned to the basal level of prewithdrawal expression, whereas c-fos expression remained two to three times the basal level. The expression of c-jun, c-fos and TIS 21 followed a more complex pattern than that of egr-l and TIS11. Although a peak of c-jun, c-fos and TIS 21 expression also occurred at 22 hr after withdrawal, significant, although variable expression, was observed in some experiments as early as $6 \mathrm{hr}$ after NGF deprivation. Following the peak of expression at $22 \mathrm{hr}$ after withdrawal, expression declined to basal levels as did $e g r-1$ and TISII earlier, throughout the commitment period (Fig. 4).

The expression of IEGs at 6-22 hr postwithdrawal is a consequence of selective induction relative to GAPDH, not of selective stabilization of IEG transcripts. The yield of mRNA declines only slightly over this period, from $\approx 13 \mu \mathrm{g}$ polyadenylated mRNA from $4 \times 10^{7}$ control cells to $\approx 10 \mu \mathrm{g}$ polyadenylated mRNA obtained from $4 \times 10^{7}$ cells plated and deprived of NGF for $14 \mathrm{hr}$. After $24 \mathrm{hr}$ in the absence of NGF, the yield of mRNA does decline: $\approx 7 \mu \mathrm{g}$ of polyadenylated mRNA was obtained from $4 \times 10^{7}$ cells plated and deprived of NGF for 26 hr. However, IEG mRNA levels decline relative to GAPDH mRNA at this time, indicating that IEG transcripts are selectively degraded even as the amount of mRNA in the culture declines. By $48 \mathrm{hr}$ after NGF withdrawal, $<4 \mu \mathrm{g}$ mRNA could be obtained from $4 \times 10^{7}$ cells originally plated.

c-fos, TIS11, egr-1, c-jun, and TIS21 are members of a set of genes expressed in PC12 cells in response to a variety of stimuli including EGF, phorbol esters, NGF and elevated intracellular calcium (Greenberg et al., 1985; Kujubu et al., 1987; Milbrandt, 1987), P. W. Mesner and S. H. Green, unpublished observations).

\section{Non-neuronal PC12 Cells Serum Withdrawal}

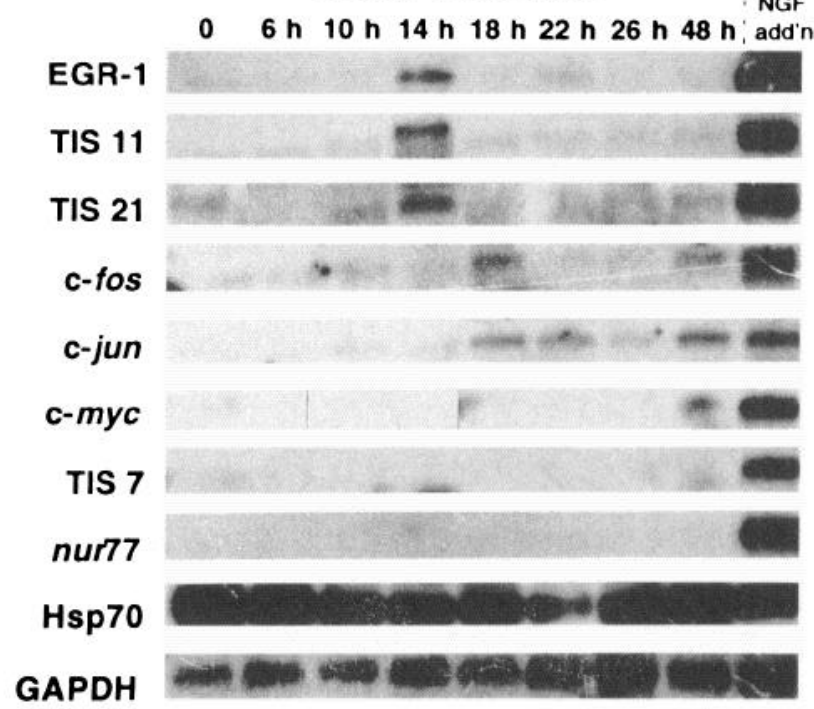

Figure 5. IEG expression in non-neuronal PC12 cells following serum withdrawal. Polyadenylated mRNA ( $2 \mu \mathrm{g} / \mathrm{lane})$ was prepared from nonneuronal $\mathrm{PC} 12$ cell cultures deprived of serum for various times. Blots were probed for expression of the IEGs indicated. The Hsp70 probe was employed to assess expression of stress-related genes and GAPDH to assess mRNA integrity and to compare loading among the lanes. mRNA from PC12 cells treated with NGF at $50 \mathrm{ng} / \mathrm{ml}$ for $1.5 \mathrm{hr}$ was employed as a positive control for IEG expression.

c-myc, TIS7 (PC-4) and nur77 (NGFI-B) are also induced by these stimuli (Greenberg et al., 1985; Milbrandt, 1988; Tirone and Shooter, 1989; P. W. Mesner and S. H. Green, unpublished observations). The expression pattern observed here following NGF withdrawal is distinctive in that expression of the latter genes does not occur (Fig. 4).

To address the possibility that the observed pattern of IEG induction was a consequence of PCD-associated cell stress or regulatory dysfunction, we analyzed the expression of the genes Hsp70 and GAPDH. No change in the level of expression of the stress-related gene Hsp70 was observed at any time after NGF withdrawal. Likewise, expression of the metabolic housekeeping gene GAPDH did not change after NGF withdrawal.

\section{IEG expression in serum-deprived non-neuronal (chromaffin- like) PC12 cells}

$\mathrm{PCD}$ in trophic factor-deprived non-neuronal PC12 cells is not inhibited by inhibitors of macromolecular synthesis. We nevertheless evaluated IEG expression in non-neuronal cells to compare it with that observed during neuronal cell PCD. Northern blot analysis was performed on non-neuronal PC12 cell cultures deprived of serum and maintained in serum-free medium for various times. Surprisingly, a pattern of IEG expression similar to that in NGF-deprived neuronal PC12 cells was observed: egr$1, T I S 11, T I S 21$, c-fos, and c-jun were all transiently induced in serum-deprived non-neuronal PC12 cells (Fig. 5). The time of expression, following serum withdrawal, was accelerated somewhat relative to neuronal $\mathrm{PC} 12$ cells. A transient three- to fourfold increase in the expression of egr-1, TISII, and TIS 21 mRNA was observed about $14 \mathrm{hr}$ after serum-deprivation and a transient induction of c-fos was observed at about $18 \mathrm{hr}$ after serum withdrawal. c-jun induction, was first detectable $18 \mathrm{hr}$ 
after serum withdrawal, and showed fluctuating and variable expression at all later time points. With the exception of c-jun, expression all of the IEGs that were induced in serum-deprived non-neuronal $\mathrm{PC} 12$ cells declined to undetectable levels after 22-26 hr.

As is the case for neuronal PC12 cells, the expression of IEGs in non-neuronal PC12 cells at 6-22 hr postwithdrawal is a consequence of selective induction relative to GAPDH, not of selective stabilization of IEG transcripts. The yield of polyadenylated mRNA ( $\approx 4.4 \mu \mathrm{g} / 100 \mathrm{~mm}$ dish) was the same for control cells as for cells deprived of serum for $14 \mathrm{hr}$, the time at which maximal IEG expression was observed. The yield of mRNA dropped precipitously after $24 \mathrm{hr}$ in serum-free medium, to $\approx 0.8$ $\mu \mathrm{g}$ polyadenylated mRNA/100 mm dish at $26 \mathrm{hr}$ and to $0.4 \mu \mathrm{g} /$ $100 \mathrm{~mm}$ dish at $48 \mathrm{hr}$. IEG mRNA levels decline relative to GAPDH mRNA at this time, as is the case for neuronal PC12 cells, again indicating that IEG transcripts are selectively degraded even as the amount of mRNA in the culture declines.

The patterns of IEG induction in trophic factor-deprived neuronal and non-neuronal $\mathrm{PC} 12$ cells resemble each other in the lack of induction of c-myc, TIS7 and nur 77 and the constitutive, unchanging expression of Hsp70 and GAPDH (Fig. 5). Despite the fact that non-neuronal $\mathrm{PC} 12$ cells die in a transcription and translation-independent manner, the overall pattern of IEG inductions is quite similar to that seen in NGF-deprived neuronal PC12 cells.

The major difference between neuronal and non-neuronal PC12 cells lies in the timing of IEG induction following withdrawal of trophic support. In neuronal PC12 cells the peak of IEG expression was at 20-22 hr after NGF withdrawal. In nonneuronal cells the peak occurred 14-18 hr after serum withdrawal (compare Figs. 4 and 5) 4-8 hr earlier than in neuronal PC12 cells. In a few experiments elevated expression of egr-I, TISII, TIS21, c-fos and c-jun was detected as soon as $6 \mathrm{hr}$ after serum withdrawal in non-neuronal PC12 cells (data not shown).

The presence of IEG expression in apoptotic non-neuronal $\mathrm{PC} 12$ cells is remarkable because it has been previously shown (Rukenstein et al., 1991; Mesner et al., 1992) that these cells die by an transcription-independent mechanism. Specifically, our previous results (Mesner et al., 1992) showed that the death of non-neuronal $\mathrm{PC} 12$ cells was not inhibited by treatment with cycloheximide (CHX) or actinomycin D (AMD) at concentrations that reduced ${ }^{35} \mathrm{~S}$-methionine incorporation into TCA-precipitable material to about $2 \%$ of control levels (Martin et al., 1988; Mesner et al., 1992). However, under such conditions IEG transcription is induced because the negative feedback effect of IEG protein products on transcription of the genes encoding them is removed, a phenomenon known as "superinduction" (Greenberg et al., 1986). Superinduction might allow sufficient protein synthesis of IEG products to effect cell death in nonneuronal $\mathrm{PC} 12$ cells, negating the effect of the macromolecular synthesis inhibitors. We assayed the level of egr-l protein by Western blotting in non-neuronal PC12 cells treated with NGF in the presence or absence of CHX or AMD. This treatment was chosen rather than NGF withdrawal because IEG expression is at a greater level following trophic factor addition than it is during PCD, making it more likely that some expression might escape inhibition by $\mathrm{CHX}$ or AMD.

Cotreatment of non-neuronal PC12 cells with NGF and CHX or AMD (both inhibitors at $3 \mu \mathrm{g} / \mathrm{ml}$ ) reduced $e g r-1$ expression below the level of detection, relative to the NGF-treated control (Fig. 6). Our results indicate that the concentrations of $\mathrm{CHX}$ and

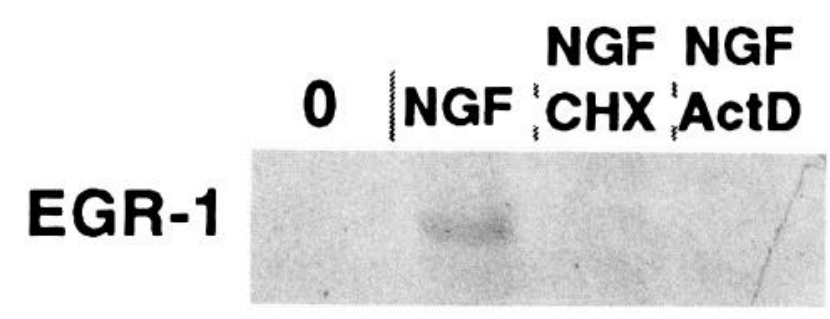

Figure 6. Expression of egr-l protein in non-neuronal PC12 cells is blocked by inhibitors of macromolecular synthesis. Chromaffin-like PC12 cell cultures untreated $(O)$, or treated for $1.5 \mathrm{hr}$ with $50 \mathrm{ng} / \mathrm{ml}$ NGF alone $(N)$, NGF $+3 \mu \mathrm{g} / \mathrm{ml}$ cycloheximide $(N G F / C H X)$, or NGF $+3 \mu \mathrm{g} / \mathrm{ml}$ actinomycin D $(N G F / A c t D)$. The cells were lysed in SDSPAGE sample buffer; $20 \mu \mathrm{g}$ were separated by SDS-PAGE and transferred to nitrocellulose. Western blotting was performed as described in Materials and Methods.

AMD previously used to block protein synthesis in trophic factor-deprived non-neuronal cells did effectively block IEG expression. Thus, it is likely that non-neuronal PC12 cells can undergo PCD without gene expression even though an IEG expression pattern similar to that in neuronal PC12 cells was observed here.

\section{IEG expression in serum-deprived Rat-1 fibroblasts}

The above observations suggest that the pattern of IEG expression during PCD is very similar to that in neuronal and nonneuronal cells. To further explore this possibility, we analyzed IEG expression in trophic factor-deprived Rat-1 fibroblasts. These cells have been previously used for studies of apoptosis (e.g., Evan et al., 1992) because they undergo PCD following serum withdrawal. Northern blot analysis was performed on cultures deprived of serum and maintained in serum-free medium for various lengths of time. In general, the pattern of IEG expression in serum-deprived Rat-1 fibroblasts, with respect to the identity of genes induced, is similar to that observed in nonneuronal and neuronal PC12 cell cultures following trophic factor deprivation. The only exception is a variable expression of nur77 in Rat-1 cells. Although the patterns of IEG expression in Rat-1 cells were much more variable than in $\mathrm{PC} 12$ cells, we consistently found elevated levels of egr-1, TIS11, TIS 21, c-fos, and c-jun mRNAs after serum withdrawal (Fig. 7). Expression of $e g r-1$ increased four- to fivefold between $10-18 \mathrm{hr}$ of serum deprivation, after which expression declined to $2-3 \times$ control by $22 \mathrm{hr}$ after withdrawal and remained at this level. Levels of TISII, TIS 21 and c-fos mRNAs were increased approximately two- to threefold after 6-10 hr of trophic factor deprivation. Expression of these three IEGs remained constant until about 22-26 hr after serum withdrawal, then declined to basal levels. As in PC12 cells c-jun expression was quite variable but a twoto threefold induction could be observed about 14-18 hr after serum-withdrawal. c-jun expression declined to basal levels by $26 \mathrm{hr}$ after serum withdrawal.

The yield of mRNA declines slowly after serum withdrawal from Rat- 1 cells. The yield from control cells, $\approx 0.5 \mu \mathrm{g} / 100 \mathrm{~mm}$ dish, is approximately the same as the yield from cells deprived of serum for $14 \mathrm{hr}, \approx 0.44 \mu \mathrm{g} / 100 \mathrm{~mm}$ dish, indicating that the increase in IEG expression at this time is the result of selective induction relative to GAPDH mRNA. The yield of mRNA declines to $\approx 0.3 \mu \mathrm{g} / \mathrm{dish}$ at $26 \mathrm{hr}$ and to $\approx 0.25 \mu \mathrm{g} / \mathrm{dish}$ at $48 \mathrm{hr}$.

As was the case in PC12 cells, induction of TIS7 and c-myc did not generally occur after serum withdrawal from Rat-1 cells, 


\section{Rat-1 Cells - Serum Withdrawal}

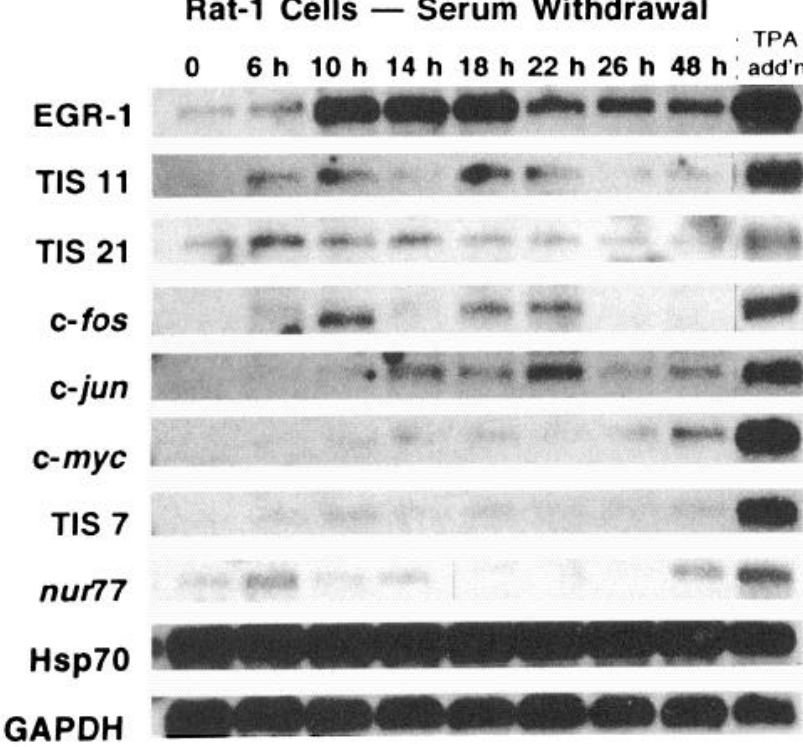

Figure 7. IEG expression in Rat-1 fibroblasts following serum withdrawal. Polyadenylated mRNA ( $2 \mu \mathrm{g} /$ lane) was prepared from Rat-1 fibroblast cultures deprived of serum for various times. Blots were probed for expression of IEGs indicated. The Hsp70 probe was employed to assess expression of stress-related genes and GAPDH to assess mRNA integrity and to compare loading among the lanes. Positive control mRNA was prepared from Rat-1 fibroblasts treated with 100 $\mu \mathrm{g} / \mathrm{ml}$ TPA for $2.0 \mathrm{hr}$.

although, in some cases, Rat-1 cultures did exhibit a two- to threefold increase in the level of c-myc mRNA after $48 \mathrm{hr}$ in serum-free medium. Unlike PC12 cells, Rat-1 cells may express nur 77 following trophic factor withdrawal. nur77 expression could be detected as early as $6 \mathrm{hr}$ after serum withdrawal. However expression of nur 77 was variable and not observed in some Rat-1 cultures. As in PC12 cells, no change in $\mathrm{Hsp} 70$ or GAPDH expression was detected in trophic factor-deprived Rat-1 cells, indicating that the IEG expression is not a stress response nor a generalized transcriptional activation.

\section{Discussion}

This study describes a timetable of molecular events occuring in neuronal PC12 cells following trophic factor deprivation. We have identified a pattern of IEG expression characteristic of neuronal PCD and placed it within the temporal context of events following withdrawal of NGF from neuronal PC12 cells (Fig.
8). These events include cessation of intracellular trophic signaling, commitment to the cell death fate, and the actual death of the cells-as determined here by appearance of DNA fragmentation and previously (Mesner et al., 1992) by loss of trypan blue exclusion. We find that neuronal PC12 cells become committed to PCD over a period 10-20 hr following NGF withdrawal. This is similar to the commitment time course previously reported by Pittman and colleagues (Pittman et al., 1993) for a variant $\mathrm{PC} 12$ cell line. The commitment time courses for neuronal PC12 cells closely resemble those reported for rat sympathetic neurons (Martin et al., 1992; Deckwerth and Johnson, 1993; Edwards and Tolkovsky, 1994), further establishing neuronal PC12 cells as a reliable model for neuronal PCD.

Ras activity declines rapidly after withdrawal of trophic factor, within 2-4 hr, well before the onset of commitment to PCD. While c-jun and TIS 21 are initially expressed prior to commitment, inductions of some IEGs, for example, c-fos, TISII, and egr-l do not occur until the end of the commitment period. DNA fragmentation and cell dissolution begin about $24 \mathrm{hr}$ after NGF withdrawal, at least $4 \mathrm{hr}$ after all cells are committed to PCD.

\section{Trophic signaling and commitment to PCD}

Our data show a gap of at least $6 \mathrm{hr}$ between the cessation of Ras activity and the earliest time at which cells begin to become committed to PCD. An important question is what process(es), evidently reversible, occupy this period. One possibility is that other protein-tyrosine kinase effectors are more persistent than Ras after NGF is removed. This is an important consideration given that PI-3-K has been implicated as a primary effector of trophic signaling (Yao and Cooper, 1995). However, tyrosine phosphorylation of high molecular weight proteins declines at least as fast as does Ras activity after transient activation by EGF (Qiu and Green, 1992), making it unlikely that proteintyrosine kinases activate PI-3-K or other effectors longer than they do Ras.

Another possibility is that protein kinases downstream of Ras continue to signal for some time after cessation of Ras activity and that it is their eventual inactivation that establishes commitment. This seems unlikely given that kinases of this sort, MAP kinases (Qiu and Green, 1992; Heasley, 1992, \#5642; Nguyen, 1993, \#6291) and S6 kinases (Nguyen et al., 1993), inactivate with a time course similar to Ras inactivation following transient activation by EGF. Furthermore, although NGF induced MAP kinase activity persists for several hours (Qiu and Green, 1992; Heasley, 1992, \#5642; Nguyen, 1993, \#6291), it
DNA Fragmentation \& Cell Death TIS11, egr-1, c-fos Expression

\section{c-jun, TIS21 Expression}

\section{Commitment to Cell Death}

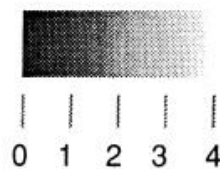

\section{Ras•GTP}

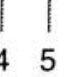

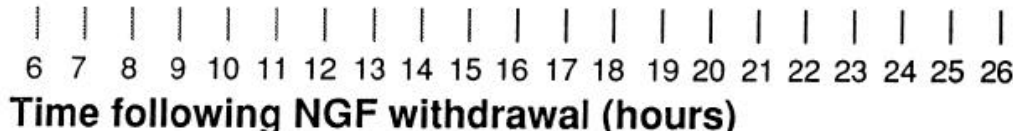

Time following NGF withdrawal (hours)

Figure 8. Diagrammatic representation of the timing of events following NGF withdrawal from neuronally differentiated PC12 cells. Ras activity declines rapidly after NGF withdrawal. Cells gradually become committed to cell death over a period of time from 10-20 hr after NGF withdrawal. IEG expression occurs at various times after NGF withdrawal but expression of some genes occurs only at the end ofor after the commitment period. Actual loss of cells does not begin until at least $24 \mathrm{hr}$ after NGF withdrawal and continues for several days thereafter. 
returns to near prestimulus levels after several days of NGF treatment (Tsao and Greene, 1991; M. S. Qiu and S. H. Green, unpublished observations). Thus, MAP kinase activity is already at a minimal level in neuronally differentiated PC12 cells before NGF withdrawal.

Alternatively, the interval between cessation of Ras signaling and onset of commitment to PCD may be due to the gradual degradation or inactivation of a constitutively active molecule that prevents PCD. Consistent with such a mechanism, proteases have been implicated in PCD in several diverse systems, including C. elegans (Yuan, 1993, \#6579), insect larval muscle (Schwartz et al., 1991), mammalian fibroblasts (Miura et al., 1993), and neurons (Gagliardini et al., 1994), and cell killing by $T$ cells (Heusel et al., 1994).

Buttyan et al. (Buttyan et al., 1988) have identified "cascades" of transcriptional inductions, involving IEGs and other genes, in PCD in prostate gland. Possibly, such transcriptional cascades start soon after trophic signaling ceases. If so, the early transcriptional events must not he sufficient for cell death because they are occurring long before the commitment.

\section{DNA fragmentation}

Endonuclease activity resulting in DNA fragmentation is typically a feature of PCD (Wyllie, 1980). Edwards et al. (Edwards and Tolkovsky, 1994) reported that commitment to PCD was concomitant with increased nucleolytic activity, implying that DNA fragmentation was the proximate cause of commitment. The present study argues against a causal role for DNA fragmentation in commitment to PCD. By using TUNEL staining as a direct and sensitive assay of DNA fragmentation, we find that the increase in IUNEL reactivity begins at $\approx 24 \mathrm{hr}$ after NGF withdrawal, approximately $4 \mathrm{hr}$ after all cells have become committcd to cell death. Our previous studies (Mesner et al., 1992) indicate that this is the same time at which loss of ability to exclude trypan blue is first detected. These observations imply that DNA fragmentation is associated not with commitment but, rather, with dissolution of the cell.

In previous studies of our neuronal PC12 cells, we were unable to detect an oligonucleosomal DNA "ladder" at any time after NGF withdrawal, including $\supseteq 24 \mathrm{hr}$ postwithdrawal when TUNEL reactivity was detected here. The presence of TUNEL reactivity without a detectable DNA ladder suggests that DNA is being cleaved into large fragments not resolved by standard agarose gels (e.g., $\geq 50 \mathrm{kbp}$ fragments). Even such a limited level of fragmentation would yield more than $10^{4}$ DNA termini/ nucleus capable of being labeled by TUNEL. Batistatou and Greene (Batistatou and Greene, 1991) have observed an oligonucleosomal ladder in PC12 cells undergoing PCD. Perhaps DNA fragmentation is occurring in all cascs, but PC12 cells maintained in different laboratories differ in ability to degrade DNA to smaller, oligonucleosomal fragments. Similarly, a murine fibroblast clone has been described (Ucker et al., 1992) that does not exhibit a DNA ladder during $T$ cell-induced PCD. In that case differences among the clonal lines appears to be due to differential expression of DNasel-like endonuclease activities.

\section{IEGs expressed during PCD}

Although our observation of TISII and TIS $2 I$ induction during neuronal PCD is novel, several studies have documented induction of egr-I,c-fos, and c-jun, and other IEGs, in dying neuronal cells. Expression of c-fos accompanies PCD in many cell types in vivo and in vitro (Smeyne et al., 1993). Estus et al. (Estus et al., 1994) reported induction of NGFI-A (egr-I), c-jun, c-fos, fos $\mathrm{B}$, jun $\mathrm{B}$, and $c-m y b$ in NGF-deprived, cultured rat sympathetic neurons. Similarly, Koistinaho et al. (Koistinaho et al., 1993) detected c-jun expression in lesioned sympathetic neurons in vivo.

While IEGs are expressed in response to many different stimuli, the pattern of expression differs among stimuli or among cells (Herschman, 1989). Thus, expression of a particular IEG is unlikely to be diagnostic of a particular cellular response, but exprcssion of a particular pattern of IEG expression can be. The pattern observed here in neurotrophic factor-deprived PC 12 cells is like that in sympathetic neurons (Estus et al., 1994), implying that this is a diagnostic pattern for neuronal PCD. egr-l, c-fos, c-jun, TISII, TIS2I, TIS7, c-myc, and nur 77 are coexpressed in $\mathrm{PC} 12$ cells in response to a wide variety of stimuli including the mitogen EGF, the neurotrophic factor NGF, and increased intracellular calcium (Greenberg et al., 1985; Kujubu et al., 1987; Milbrandt, 1987, 1988; Bartel et al., 1989; Mesner and Green, unpublished observations; Altin et al., 1991). In contrast, c-myc and nur77 are not expressed with the other genes during PCD in neuronal or non-neuronal trophic factor-deprived PC12 cells. Similarly, c-myc and nur 77 are not expressed during PCD in sympathetic neurons (Estus et al., 1994; Freeman et al., 1994).

Lack of nur77 expression is also seen in T-cell hybridomas undergoing PCD following IL-2 withdrawal (Liu et al., 1993; Woronicz et al., 1993). Interestingly, T-cell hybridomas induced to undergo PCD by ligation of antigen receptors express nur 77 and such expression appears to be required for PCD. This may indicate mechanistic differences between PCD induced by an extracellular signal and that induced by withdrawal of trophic factor. In addition, there may be differences among cells in the pattern of IEGs expressed during PCD. This is consistent with our observation of such differences, albeit sinall, between PCI2 and Rat-1 cells.

\section{The timing of IEG expression during PCD}

While similar genes are induced in neuronal and non-neuronal PC12 cells, following trophic factor withdrawal, the temporal pattern is different. In neuronal PC12 cells, some IEGs-for example, c-jun and TIS2 1 -are expressed within $6 \mathrm{hr}$ after $\mathrm{NGF}$ withdrawal; others-for example, egr-1, c-fos, and TISII-are not expressed until $\approx 20 \mathrm{hr}$ after NGF withdrawal, at the end of the commitment period. Non-neuronal PC12 cells exhibit IEG inductions over a range of time from 6-14 hr after serum withdrawal. This pattern reflects the time course of loss of cell viability following trophic factor withdrawal from PC 12 cells (Mesner et al., 1992): cell death appears to occur at a slower pace in neuronal PC 12 cells than in non-neuronal PC12 cells. The death time course in neuronal $\mathrm{PC} 12$ cells resembles that in sympathetic neurons (Martin et al., 1992; Deckwerth and Johnson, 1993; Edwards and Tolkovsky, 1994).

\section{Requirement for IEG expression during PCD}

Previous studies have implied a requirement for IEG expression, particularly c-jun, in neuronal PCD (Estus et al., 1994). A striking difference between neuronal and non-neuronal PC12 cells is their dependence on macromolecular synthesis during PCD. Transcription and translation inhibitors that effectively abolish IEG expression block cell death in trophic factor deprived neuronal PC12 cells but not in non-neuronal PC12 cells. Thus, the presence of IEG expression during PCD does not imply a requirement for such expression in all cells. 
The patterns of IEG expression described here presumably mirror intracellular signals and regulatory processes that are active al different times during the process of PCD. The different, complex expression patterns in the three cell types studied here imply complex regulation with different signals active in a sequence throughout the PCD process. Our description of these expression patterns thus provides a means to identify the intracellular signals active at different times during PCD. For example, the IEG expression pattern observed here argues against a role tor elevated cytosolic $\mathrm{Ca}^{2+}$ in PCD. nur77 is strongly induced by depolarization or $\mathrm{Ca}^{2+}$ ionophore in PC12 cells (Bartel et al., 1989; Hazel ct al., 1991; Mesner and Green, unpublished observations) but is not induced during PCD.

Thus, while expression of these IEGs may not be necessary for cell death in all cell types, their identification nonetheless provides a valuable means to monitor and identify intracellular regulatory events that occur during PCD. Facilitating this endeavor is the fact that considerable information regarding the regulation of many IEGs already exists, including descriptions of flanking sequences containing their transcription regulatory elements.

\section{References}

Altin JG, Kujubu DA, Raffioni S, Eveleth DD, Herschman HR, Bradshaw RA (1991) Differential induction of primary-response (TIS) genes in $\mathrm{PC} 12$ pheochromocytoma cells and the unresponsive variant PC12 ${ }^{\text {nnrs. J }}$ Jiol Chem 266:5401-5406.

Badley JE, Bishop GA, St John T, Frelinger JA (1988) A simple, rapid method for the purification of poly $A^{+}$RNA. Biotechniques $6: 114$ 116

Bar-Sagi D, Feramisco JR (1985) Microinjection of the ras oncogene protein into $\mathrm{PC} 12$ cells induces morphological differentiation. Cell 42:841-848.

Barde Y-A (1989) Trophic factors and neuronal survival. Neuron $2: 1525-1534$

Bartel DP, Sheng M, Lau LF, Greenberg ME (1989) Growth factors and membrane depolarization activate distinct programs of early response gene expression: dissociation of fos and jun induction. Genes Dev 3:304-313.

Batistatou A, Greene LA (1991) Aurintricarboxylic acid rescues PCI2 cells and sympathetic neurons from cell death caused by nerve gowth factor deprivation: correlation with suppression of endonuclease activity. J Cell Biol 115:461-471.

Borasio GD, John J, Wittinghofer A, Barde Y-A, Sendtner M, Heumann $\mathrm{R}$ (1989) ras p21 protein promotes survival and neurite outgrowth of cultured embryonic neurons. Neuron 2:1087-1096.

Buttyan R, Zakeri Z, Lockshin R, Wolgemuth D (1988) Cascade induction of c-fos, c-myc and heat shock $70 \mathrm{~K}$ transcripts during regression of the rat ventral prostate gland. Mol Endocrinol 2:650-657.

Buttyan R, Olsson CA. Pintar J, Chang C, Bandyk M, NG P-Y, Sawczuk IS (1989) Induction of the TRPM-2 gene in cells undergoing programmed death. Mol Cell Biol 9:3473-3481.

Carter AN, Downs CP (1992) Phosphatidylinositol-3-kinase is activated by nerve growth factor and epidermal growth factor in PC12 cells. J Biol Chem 267:14563-14567.

Curran T, Gordon MB, Rubino KL, Sambucetti LC (1987) Isolation and characterization of the c-fos(rat) cDNA and analysis of posttranslational modification in vitro. Oncogene 2:79-84.

Dalla-Favera R, Wong-Stahl F, Gallo RC (1982) onc gene amplification in promyelocytic leukemia cell line HL-60 and primary leukemia cells of the same patient. Nature 299:61-63.

Deckwerth TL, Johnson EM (1993) Temporal analysis of events associated with programmed cell death (apoptosis) of sympathetic neurons deprived of nerve growth factor. J Cell Biol 123:1207-1222.

Edwards SN, Tolkovsky AM (1994) Characterization of apoptosis in cultured rat sympathetic neurons after nerve growth factor withdrawal. J Cell Biol 124:537-546.

Estus S, Zaks WJ, Freeman RS, Grunda M, Bravo R, Johnson EM Jr (1994) Altered gene expression in neurons during programmed cell death: identification of c-jun as necessary for neuronal apoptosis. J Cell Biol 127:1717-1727.

Evan GI, Wyllie AH, Gilbert CS, Littlewood TD, Land H, Brooks M, Waters CM, Penn LZ, Hancock DC (1992) Induction of apoptosis in fibroblasts by c-myc protein. Cell 69:119-128.

Fletcher BS, Lim RW, Varnum BC, Kujubu DA, Koski RA, Herschman HR (1991) Structure and expression of TIS21, a primary response gene induced by growth factors and tumor promoters. J Biol Chem 266:14511-14518.

Freeman RS, Estus S, Johnson EM Jr (1994) Analysis of cell cyclerelated gene expression in postmitotic neurons: selective induction of cyclin Dl during programmed ccll dcath. Ncuron 12:343-355.

Gagliardini V, Fernandez P-A, Lee RKK, Drexler HCA, Rotello RJ, Fishman MC, Yuan J (1994) Prevention of vertebrate neuronal death by the crmA gene. Science 263:826-828.

Gavrieli Y, Sherman Y, Ben-Sasson SA (1992) Identification of programmed cell death in situ via specific labeling of nuclear DNA fragments. J Cell Biol 119:493-501.

Greenberg ME, Greene LA, Ziff EB (1985) Nerve growth factor and epidermal growth factor induce rapid transient changes in proto-oncogene transcription in PC12 cells. J Biol Chem 260:14101-14110.

Greenberg ME, Hermanowski AL, Ziff EB (1986) Effect of protein synthesis inhibitors on growth factor activation of c-fos, c-myc, and actin gene transcription. Mol Cell Biol 6:1050-1057.

Greene LA (1978) Nerve growth factor prevents the death and stimulates the neuronal differentiation of clonal $\mathrm{PC} 12$ pheochromocytunia cells in serum-free medium. J Cell Biol 78:747-755.

Greene LA, Tischler AS (1976) Establishment of a noradrenergic clonal line of rat adrenal pheochromocytoma cells which respond to nerve growth factor. Proc Natl Acad Sci USA 73:2424-2428.

Greene LA, Aletta JM, Rukenstein A, Green SH (1986) PC12 pheochromocytoma cells: culture, nerve growth factor treatment, and experimental exploitation. Methods Enzymol 147:207-216.

Hagag N, Halegoua S, Viola M (1986) Inhibition of growth factorinduced differentiation of $\mathrm{PCI} 2$ cells by microinjection of antibody to ras p21. Nature 319:680-682.

Ham J, Babij C, Whitfield J, Pfarr CM, Lallemand D, Yaniv M, Rubin LL (1995) A c-Jun dominant negative mutant protects sympathetic neurons against programmed cell death. Neuron 14:927-939.

Hazel IG, Misra R, Davis IJ, Greenberg ME, Lau LF (1991) Nur77 is differentially modified in PC12 cells upon membrane depolarization and growth factor treatment. Mol Cell Biol 11:3239-3246.

Herschman HR (1989) Extracellular signals, transcriptional responses and cellular specificity. Trends Biochem Sci 14:455-458.

Heusel JW, Wesselschmidt RL, Shresta S, Russell IH, I ey TI (1994) Cytotoxic lymphocytes require granzyme $\mathrm{B}$ for the rapid induction of DNA fragmentation and apoptosis in allogeneic target cells. Cell 76:977-987.

Kaneda N, Oshima M, Chung SY, Guroff G (1992) Sequence of a rat $T I S I I$ cDNA, an immediate early gene induced by growth factors and phorbol esters. Gene 118:289-291.

Kaplan D, Martin-Zanca D, Parada L (1991a) Tyrosine phosphorylation and tyrosine kinase activity of the trk proto-oncogene product induced by NGF. Nature 350:158-160.

Kaplan DR, Hempstead BL, Martin-Zanca D, Chao MV, Parada LF (1991b) The $t r k$ proto-oncogene product: a signal transducing receptor for nerve growth factor. Science 252:554-558.

Klein R, Jing S, Nanduri V, O'Rourke E, Barbacid M (1991) The trk proto oncogene encodes a receptor for nerve growth factor. Cell 65 : 189-197.

Koistinaho J, Pelto-Huikko M, Sagar SM, Dagerlind A, Roivainen R, Hokfelt $T$ (1993) Injury-induced long-term expression of immediate early genes in the rat superior cervical ganglion. Neuroreport 4:3740.

Kujubu DA, Lim RW, Varnum BC, Herschman HR (1987) Induction of transiently expressed genes in the $\mathrm{PC}-12$ pheochromocytoma cells. Oncogene 1:257-270.

Kure S, Tominaga T, Yoshimoto T, Tada K, Narisawa K (1991) Glutamate triggers internucleosomal DNA cleavage in neuronal cells. Biochem Biophys Res Commun 179:39-45.

Lamph WW, Wamsley P, Sassone-Corsi P, Verma IM (1988) Induction of proto-oncogene JUN/AP-1 by serum and TPA. Nature 334:629631.

Liu Z-G, Smith SW, McLaughlin KA, Schwartz LM, Osbourne BA (1993) Apoptotic signals delivered through the T-cell receptor of a 
T-cell hybrid require the immediate-early gene nur77. Nature 367 : 281-284.

Lockshin R (1969) Programmed cell death: activation of lysis by a mechanism involving the synthesis of protein. J Insect Physiol 15: $1505-1516$

Loeb DM, Maragos J, Martin-Zanca D, Chao MV, Parada LF, Greene LA (1991) The trk proto-oncogene rescues NGF responsiveness in mutant NGF-responsive PC12 cell lines. Cell 66:961-966.

Martin DP, Schmidt RE, DiStefano PS, Lowry OH, Carter JG, Johnson EM Jr (1988) Inhibitors of protein synthesis and RNA synthesis prevent neuronal death caused by nerve growth factor deprivation. $J$ Cell Biol 106:829-844.

Martin DP, Ito A, Horigome K, Lampe PA, Johnson EM Jr (1992) Biochemical characterization of programmed cell death in NGF-deprived sympathetic neurons. J Neurobiol 23:1205-1220.

McConkey DJ, Hartzell P, Nicotera P, Orrenius S (1989) Calcium-activated DNA fragmentation kills immature thymocytes. FASEB J 3:1843-1849.

Mesner PW, Winters TR, Green SH (1992) NGF withdrawal-induced cell death in neuronal $\mathrm{PC} 12$ cells resembles that in sympathetic neurons. J Cell Biol 119:1669-1680.

Milbrandt J (1987) A nerve growth factor-induced gene encodes a possible transcriptional regulatory factor. Science 238:797-799.

Milbrandt J (1988) Nerve growth factor induces a gene homologous to the glucocorticoid receptor gene. Neuron $1: 183-188$.

Miura M, Zhu H, Rotello R, Hartweig EA, Yuan J (1993) Induction of apoptosis in fibroblasts by IL-1 $\beta$-converting enzyme, a mammalian homolog of the $C$. elegans cell death gene ced-3. Cell 75:653-660.

Mobley WC, Schenker A, Shooter EM (1972) Characterization and isolation of proteolytically modified nerve growth factor. Biochemistry 15:5543-5552.

Nguyen TT, Scimeca JC, Filloux C, Peraldi P, Carpentier JL, Van Obberghen $\mathrm{E}$ (1993) Co-regulation of the mitogen-activated protein kinase, extracellular signal-regulated kinase 1 , and the $90 \mathrm{kDa}$ ribosomal S6 kinase in PC12 cells. Distinct effects of the neurotrophic factor, nerve growth factor, and the mitogenic factor, epidermal growth factor. J Biol Chem 268:9803-9810.

Noda M, Ko M, Ogura A, Liu DG, Amano T, Takano T, Ikawa Y (1985) Sarcoma viruses carrying ras oncogenes induce differentiation-associated properties in a neuronal cell line. Nature 318:73-75.

Ohmichi M, Decker SJ, Saltiel AR (1992) Activation of phosphatidylinositol-3 kinase by nerve growth factor involves indirect coupling of the trk proto-oncogene with sre homology 2 domains. Neuron 9:769-777.

Oppenheim RW (1991) Cell death during development of the nervous system. Annu Rev Neurosei 14:453-501.

Osbourne BA, Schwartz LM (1994) Essential genes that regulate apoptosis. Trends Cell Biol 394-399.

Pittman RN, Wang S, DiBenedetto AJ, Mills JC (1993) A system for characterizing cellular and molecular events in programmed neuronal cell death. J Neurosci 13:3669-3680.

Pratt RM, Greene RM (1976) Inhibition of palatal epithelial cell death by altered protein synthesis. Dev Biol 54:135-145.

Qiu M-S, Green SH (1991) NGF and EGF rapidly activate $\mathrm{p}^{2} 1^{\prime a s}$ in
PC12 cells by distinct, convergent pathways involving tyrosine phosphorylation. Neuron 7:937-946.

Qiu M-S, Green SH (1992) PC12 cell neuronal differentiation is associated with prolonged $\mathrm{p} 21^{\text {ras }}$ activity and consequent prolonged tyrosine phosphorylation of ERKs. Neuron 9:705-717.

Rukenstein A, Rydel RE, Greene LA (1991) Multiple agents rescue PC12 cells from serum-free cell death by translation- and transcrip tion-independent mechanisms. J Neurosci 11:2552-2563.

Schwartz LM, Smith S, Jones ME, Osborne BA (1991) Two distinct molccular mechanisms mediate programmed cell death. Soc Neurosci Abstr 17:228.

Scott SA, Davies AM (1990) Inhibition of protein synthesis prevents cell death in sensory and parasympathetic neurons deprived of neurotrophic factor in vitro. J Neurobiol 21:630-638.

Smeyne RJ, Vendrell M, Hayward M, Baker SJ, Miao GG, Schilling K, Robertson LM, Curran I, Morgan JI (1993) Continuous e-fos expression precedes programmed cell death in vivo. Nature 363:166169.

Soltoff SP, Rabin SL, Cantley LC, Kaplan DR (1992) Nerve growth factor promotes the activation of phosphatidylinositol 3-kinase and its association with the trk tyrosine kinase. J Biol Chem 267:1747217477 .

Szeberényi J, Cai H, Cooper GM (1990) Effect of a dominant inhibitory Ha-ras mutation on neuronal differentiation of PC.12 cells. Mol Cell Biol 10:5324-5332.

Tata JR (1966) Requirement for RNA and protein synthesis for induced regression of the tadpole tail in organ culture. Dev Biol 13:77-94.

Tirone F, Shooter EM (1989) Early gene regulation by nerve growth factor in $\mathrm{PCl} 2$ cells: induction of an interferon-related gene. Proc Natl Acad Sci USA 86:2088-2092.

Tsao H, Greene LA (1991) The roles of macromolecular synthesis and phosphorylation in the regulation of a protein kinase activity transiently stimulated by nerve growth faclor. J Biol Chem 266:1298112988 .

Tso JY, Sun X-H, Kao T-H, Reece KS, Wu R (1985) Isolation and characterization of rat and human glyceraldehyde-3-phosphate dehydrogenase cDNAs: genomic complexity and molecular evolution of the gene. Nucleic Acids Res 13:2485-2502.

Ucker DS, Obermiller PS, Eckhart W, Apgar JR, Berger NA. Meyers J (1992) Genome digestion is a disposable consequence of physiological cell death mediated by cytotoxic T lymphocytes. Mol Cell Biol $12: 3060-3069$

Varnum BC, Lim RW, Herschman HR (1989) Characterization of TIS7, a gene induced in Swiss 3 T3 cells by the tumor promoter tetradecanoyl phorbol acetate. Oncogene 4:1263-1265.

Woronicz JD, Calnan B, Ngo V, Winoto A (1993) Requirement for the orphan steroid receptor Nur77 in apoptosis of T-cell hybridomas. Nature 367:277-281.

Wyllie AH (1980) Glucocorticoid-induced thymocyte apotosis is associated with endogenous endonuclease activation. Nature 284:555556.

Wyllie AH, Morris RG, Smith AL, Dunlop D (1984) Chromatin cleavage in apotosis: association with condensed chromatin morphology and dependence on macromolecular synthesis. J Pathol 142:67-77.

Yao R, Cooper GM (1995) Requirement for phosphatidylinositol-3 kinase in the prevention of apoptosis by nerve growth factor. Science $267: 2003-2006$ 